\title{
Methodological Foundations of the Risk of the Stock Markets of Developed and Developing Countries in the Conditions of the Crisis
}

\author{
Diana Burkaltseva ${ }^{1,2}\left(\mathbb{0}\right.$, Shakizada Niyazbekova ${ }^{3,4, *(\mathbb{D})}$, Lyudmila Borsch ${ }^{5}$, Mir Abdul Kayum Jallal ${ }^{6}$, \\ Nataliya Apatova ${ }^{7}$, Ardak Nurpeisova ${ }^{8} \mathbb{D}$, Alexander Semenov ${ }^{9}$ and Ayagoz Zhansagimova ${ }^{10}$ \\ 1 Department of Economics and Management, V.I. Vernadsky Crimean Federal University, \\ 295007 Simferopol, Russia; di_a@mail.ru \\ 2 Department of Media Communications, Media Technologies and Design, V.I. Vernadsky Crimean \\ Federal University, 295007 Simferopol, Russia \\ 3 Department of Banking and Financial Markets, Financial University under the Government of the Russian \\ Federation, 125993 Moscow, Russia \\ 4 Research and Education Center "Sustainable Development", Moscow Witte University, \\ 125993 Moscow, Russia \\ 5 Departments of Enterprise Finance and Insurance, V.I. Vernadsky Crimean Federal University, \\ 295007 Simferopol, Russia; 1-borsh49@mail.ru \\ 6 Departments of Finance and Credit, V.I. Vernadsky Crimean Federal University, 295007 Simferopol, Russia; \\ akjallal@mail.ru \\ check for \\ updates \\ Citation: Burkaltseva, Diana \\ Shakizada Niyazbekova, Lyudmila \\ Borsch, Mir Abdul Kayum Jallal, \\ Nataliya Apatova, Ardak \\ Nurpeisova, Alexander Semenov, \\ and Ayagoz Zhansagimova. 2022. \\ Methodological Foundations of the \\ 7 Departments of Business Informatics and Mathematical Modeling, V.I. Vernadsky Crimean Federal University, \\ 295007 Simferopol, Russia; apatova@list.ru \\ 8 Department of Information and Communication Technologies, Faculty of Computer Systems and Professional \\ Education, S. Seifullin Kazakh Agro Technical University, Nur-Sultan 010000, Kazakhstan; \\ nurpeisova.ardak81@gmail.com \\ 9 Administration, Moscow Witte University, 115432 Moscow, Russia; ASemenov@muiv.ru \\ 10 Department of Geography, Land Management and Cadastre, Faculty of Geography and \\ Environmental Management, Al-Farabi Kazakh National University, Almaty 050000, Kazakhstan; \\ ayagoz.zhansagimova@mail.ru \\ * Correspondence: shakizada.niyazbekova@gmail.com; Tel.: +7-926-974-84-32
} Risk of the Stock Markets of Developed and Developing Countries in the Conditions of the Crisis. Journal of Risk and Financial Management 15: 3. https://doi.org/ 10.3390/jrfm15010003

Academic Editor: Thanasis Stengos

Received: 21 September 2021

Accepted: 26 November 2021

Published: 22 December 2021

Publisher's Note: MDPI stays neutral with regard to jurisdictional claims in published maps and institutional affiliations.

Copyright: (C) 2021 by the authors. Licensee MDPI, Basel, Switzerland. This article is an open access article distributed under the terms and conditions of the Creative Commons Attribution (CC BY) license (https:// creativecommons.org/licenses/by/ $4.0 /)$.
Abstract: The development of a methodology for the growth of the stock market through a deep transformation of the economic development system and introduction of digital technologies. The article is devoted to the study of the development of stock markets' actual problems that affect the redistribution of capital between sectors of the economy by using tools and mechanisms between the financial and stock markets. The purpose of the study is to improve the regulatory segment of the stock market in order to further develop stock exchanges, integrate them into the global economic system, and attract investment in the economy. To achieve the goal, the following tasks were performed: the development of the London Stock Exchange was analyzed and the profit growth was determined; a comparative capitalization of the main stock instruments was carried out; internal factors of influence on the stock market were determined. The problem of the international stock market in all countries with emerging markets, first of all, lies in the improvement of the institutional environment, which is a prerequisite for the stability of the stock market. To analyze the development of stock markets, natural technical sciences were used to identify objective patterns, and determine the state and motives, using various methods and techniques: logic, generalizations, specific methods of cognition, comparison, and graphics. In the development of the stock market, the economy establishes certain natural actions in the real sector of the economy through a regulatory system of measures, and the needs of investments in the real sector of the economy, methods, and tools are used to achieve the desired results. Statistical, analytical, and dynamic methods were used. The essential foundations of the importance of stock markets and the economy are revealed; we discuss the penetration of knowledge and the conduction of a deep transformation through the introduction of digital technologies in all spheres of the economy, including the transformation of the development of the stock and financial markets nowadays. Results. The assessment of the state of securities markets in developed and developing countries is made on the example of the largest 
stock exchanges in Brazil and the United Kingdom. The features of the effective functioning of stock markets are revealed. The hypothesis is put forward about the insufficiency of research on the stock market of developed and developing countries and the mechanisms used having an insufficient impact on the development of the economy. From this point of view, an analysis of the dynamics of the current state of the issuers' number and the dynamics of profitability of developed markets is carried out, the comparative capitalization volumes of the stock markets of Great Britain and Brazil are evaluated, and the weaknesses of their functioning are identified. Conclusions. The conducted research shows that countries, where stock markets are successfully functioning and developing, are catalysts for economic development and the accumulation of funds. Each country applies models of stock market development and a strategy for its regulation in accordance with the concept of a functioning market and its maturity.

Keywords: stock market; security; stock market comparison; B3; London Stock Exchange; mechanism; tools

\section{Introduction}

Based on generally accepted theories, the stock market is one of the well-known components of the market economy, which is a modern tool for the reproduction processes of macroeconomic development. Consequently, the stock market has a complex structure and sometimes its real purpose lies behind it. The redistribution of capital between areas where the productivity of its use is low and areas that require capital for normal functioning is the key to economic development. This mechanism functions thanks to the financial market - an important component of which is the stock market. In the conditions of the existence of a market system, the stock market is a powerful institution that transforms monetary resources into capital.

Given the current trends in the growth of the financial sector, it is important to focus on the development of stock markets. The functions of the stock market include the folding system of the economic relations of agents: the consumer and the supplier of capital. The knowledge of the essence of the development of the stock market requires an answer to these questions: What operations are performed in the process of its development in the market? What qualities determine the development process? What are the specifics in the existing economic relations between its subjects? The answers to these questions follow from the essence of the stock market and functions that the stock market should perform. In this study, social technologies were applied in the field of stock market management, using reasonable, specially created empirical tools (methods, rules, procedures) and influencing the behavior of the subjects of the management process in order to create a typification of economic activity to attract investment in the real sector of the economy.

\section{Materials and Methods}

\subsection{The Main Challenges in the Development of Stock Markets Nowadays}

In the stock market, the movement of capital occurs through the redistribution of securities. For the issuer of securities, this is an opportunity to obtain the desired capital, and for the investor, it is an opportunity to achieve income due to the investment of his temporarily free resource. In addition, the securities market attracts not only large investors to the investment process but also those who own insignificant amounts of funds. Therefore, due to stock exchanges, small owners' funds are accumulated to the size that is necessary for the needs of economic development (Parker Simon 2018).

In the theoretical aspect, the formation and development of the stock market at the macro level is studied in the works (Borshch 2018b; Kulikova 2018; Kutuzova 2015). The spatial development of the institutional infrastructure of the stock market in Russia was studied in the works of domestic economists, where the main characteristics of the institutional infrastructure are disclosed (Ananev 2012; Zaharova and Vilisova 2016). At this 
stage of development, globalization represents the interdependencies and interconnections of national economies in the global financial markets; these processes contribute to the withdrawal of business outside the state, formation of the global information space, and knowledge becoming a key component of the wealth of society. According to Saifiev and Soloviev (2019), in the "modern conditions of the development of the world economy and the spread of financial globalization processes", the attention of scientists is focused on the study of "international financial centers' functioning specifics". According to the authors, international financial centers are constantly transforming and developing in step with the times, and they are able to move billions of capital and form international financial markets. Considering the development of financial markets from the legislative side, there is a process of deepening regulation of the market; the legislation itself is a certain regulatory instrument with the law defining the participants and the subject of relations between them. Considering the arguments of (Ferreira et al. 2018) and regarding the laws in the financial market, in our opinion, it should not turn into a regulator, but rather be considered as a large system of all its participants, which should rely on its own regulatory framework, an independent body of state regulation, and certain control.

From a scientific point of view, the investment component in the financial market is mainly the primary market, whose share consists of several percent in relation to the turnover of the secondary market, where there is an endless resale of financial assets.

According to Borsch (2018a), the stock market is a kind of reflection of the business activity of the state and its internal state (Borsch 2018a; Andrey and Ushakov 2015; Filatova 2017). One can agree with the author's position because of the features of the stock market, the inclusion of Russia in the system of the global financial market, and the assignment of international credit ratings to the state that affects the economic development of Russia. The stock market is a developed system that ensures the turnover of securities and has a fairly developed market infrastructure, including market entities: investment funds, banks, exchanges, and companies. Considering the "development of the global system" of financial markets, we will examine it from the point of view of three subsystems: global (where world finance operates); global (uniting world reproductive systems); national financial systems (in terms of elements forming global financial flows) (Ivanova et al. 2021).

In our opinion, this becomes an incentive for the process of reproduction and financial relations that goes beyond national borders. From the point of view of the financial system, it cannot achieve stability without an effective system of internal corporate risk control in financial institutions and their state regulation with the use of risk management.

\subsection{Formation of a Modern Financial Market Model}

The processes of development of the global financial system, which have become a consequence of financial globalization, have created the prerequisites and conditions for the formation of a world finance system in which classical and newly created forms of cash flows, including virtual ones, have become objects of purchase and sale on the global financial market.

To study the peculiarities of the development of the national financial market of the Russian Federation in the context of the transformation of the world finance system, it is necessary to define conceptual approaches to institutional and functional understanding.

For these purposes, we will draw a clear distinction between the categories of global, international, regional, and national financial markets. According to the authors, the national financial market is a set of relations between participants in the financial market of a given country regarding the purchase and sale of financial products and services that are not accompanied by the import and export of capital from the country.

As for the international financial market, having separated itself from the national markets in terms of conducting external (foreign) transactions, it closely connects all national markets at the international level, functioning on the basis of the norms and rules of the current international monetary and financial system, ensuring cross-border redistribution of capital. The international financial market connects all national financial 
markets at the international level and is also the main factor in the formation and subsequent development of such a modern economic phenomenon as financial globalization. The international financial market cannot exist separately from national markets, it is based on them since nothing different happens on the international stock market from what would not happen on national financial markets.

Concretizing this statement, we can clarify the following:

- the international financial market is based, on the one hand, on national financial markets and national organizations;

- $\quad$ financial instruments of infrastructure regulating these markets;

- $\quad$ on international organizations and their infrastructure; regulations that include:

- $\quad$ international stock and currency exchanges;

- $\quad$ international clearing systems;

- $\quad$ settlement and depository services;

- $\quad$ syndicates of multinational banks that are located in the territory of specific countries are the residents of the USA, Japan, Switzerland, Great Britain, and France.

The international financial market does not include the internal operations of national financial markets but connects all new financial markets at the international level. The degree of involvement of national financial markets in the operations of the international financial market is determined by a number of factors. Local macroeconomic factors determining the participation of national and regional financial markets in the functioning of international financial markets reflect not only the state of the national economy but also confirm the readiness of the national market to integrate into the international financial market. Global macroeconomic factors reflect trends and prospects for the development of the global economic system and rapid evolution.

The classification of factors determining the participation of national financial markets in the operations of the international financial market include: macroeconomic; geopolitical, geo-economic, and the economic situation of the country; these include: the national economy, external debt, and reserves. The country's position in the global economy is shown through:

- $\quad$ indicators of the balance of payments, the interest of the leading countries of the world community in the integration of the country into the world economic system;

- $\quad$ the level of development of the national financial system;

- development of the international monetary and financial system;

- $\quad$ the role of the country in the international division of labor;

- the level of organization of the national financial market and its segments;

- the level of organization of the international financial market;

- $\quad$ the country's place in the world economy system;

- development of the institution of financial intermediaries;

- development of international financial intermediaries;

- the level of development of the IEO of the country, the level of tax liberalization;

- $\quad$ the degree of integration of the country into the global monetary and financial system;

- $\quad$ the level of capital movement liberalization;

- geographical location;

- quality of the international solvency rating;

- $\quad$ stability of the global geopolitical situation.

Factors ensuring the stability of the national economy affect the possibilities of its adaptation to new trajectories of development of international financial relations. The classification of these factors includes two groups of systemic factors, internal and external. Systematization of the factors affects the stability of the national economy and the possibility of its adaptation to new external conditions.

Factors of stability of the national economy and internal factors of influence include:

- macroeconomic situation in the country;

- production and investment activity; 
- development of the financial and banking sector;

- $\quad$ the state of the balance of payments and external factors;

- monetary policy;

- trends in capital outflow/inflow;

- currency policy.

Internal and external factors are in a systematic relationship that have an impact on economic sustainability. The influence of external factors is associated with structural transformations in the global economy, the risks of protectionism, and sanctions confrontation in international trade. The impact of internal factors happens due to the transitional status of the Russian economy, in which the process of the formation of market institutions takes place in an insufficiently developed market environment within the framework of a mixed institutional model of the economy. The role of the state in such a paradigm of the reproduction process is objectively very significant and is realized through the activities of system-forming companies and banks with state participation, the policy of subsidizing interest rates, the provision of budgetary support to enterprises, and financial organizations by public administration bodies. The position of assessing the impact of the macroeconomic situation on economic stability and the content of the concept of sustainability characterize indicators of financial stability, on the one hand, and indicators of economic growth assessment, on the other. The basic indicators characterizing macroeconomic stability are: GDP dynamics, federal budget surplus/deficit (in \% of GDP), total public debt (in \% of GDP), consumer price index, average interest rate on loans (Thai-Ha and Chang 2011; Taylan and Tatlidil 2013). Unprecedented stimulus after the rapid collapse in February-March 2019, meant that financial markets recovered surprisingly quickly. The US stock market has almost completely recovered from its losses.

Emerging market currencies have been steadily strengthening since May 2020. Government debt rates remain at historically low levels, despite the rapid increase in public debt. The main reason for the rapid recovery of financial markets was the unprecedented monetary and budgetary stimulus measures that the leading economies promptly began to implement. The US cut its interest rate to zero and began a large-scale quantitative easing program. Other major central banks have also started buying assets on their balance sheets, pumping liquidity into the market. The total amount of support through the quantitative easing channel will reach about $20 \%$ of GDP. The Fed and the ECB assured the markets that support will be provided in the necessary amounts and will continue for the necessary time until the economies reach the trajectory of achieving the goals of regulators. Thus, unlike the financial crisis of 2008-2009, central banks acted decisively and quickly in 2020. This allowed us to quickly extinguish the financial panic that reigned in the markets. Central banks can provide free liquidity on almost an unlimited scale. This supports financial markets and saves investors from losses. However, these measures will not help to avoid an economic downturn. According to the latest forecasts of the World Bank, global GDP will decline by $5 \%$ in 2020 . According to NBER estimation, the American economy entered a recession back in February 2020. The Fed expects the US economy to contract by $6.5 \%$. The ECB expects that the decline in the GDP of the eurozone countries will be $8.7 \%$. Therefore, there is currently a sharp gap between optimistic sentiment in financial markets and macroeconomic dynamics.

\section{Results}

\subsection{Development of the Stock Market in Russia}

For a better understanding of the situation unfolding on the global stock market, it is worth considering up-to-date statistical information. According to the statistics of the World Federation of Exchanges (WFE), the following trends were observed in the market for the first half of 2019: the global market capitalization increased by $1.6 \%$ compared to the first half of 2018; the value of shares traded on exchanges decreased by $11 \%$, where the number of transactions increased by $11.4 \%$ worldwide; the number of companies registered on exchanges decreased by $0.5 \%$ compared to the previous year. In general, new listings 
and investment flows fell in the first six months of 2019; the volume of exchange-traded derivatives increased (Investopedia 2020).

It should be noted that the situation on the Russian stock market in 2018 was not the worst; despite the pressure of the European Union on the Russian economy the market survived. Considering the results of changes in the indices in USD terms, it is clear that in the same year of 2018, the American indices declined amounting to $4.7 \%$; if we consider the European platforms, their losses were much higher and amounted to $11-22 \%$. The capitalization of companies is determined by the company's revenue and the analysis of the basic multipliers. The most popular ones are defined (P/E, P/S, EV/EBITDA). We will conduct a rating of the most significant Russian issuers (Figure 1). This ranking is based on the revenue indicator. The figure does not show all the indicators used as tools due to the lack of data.

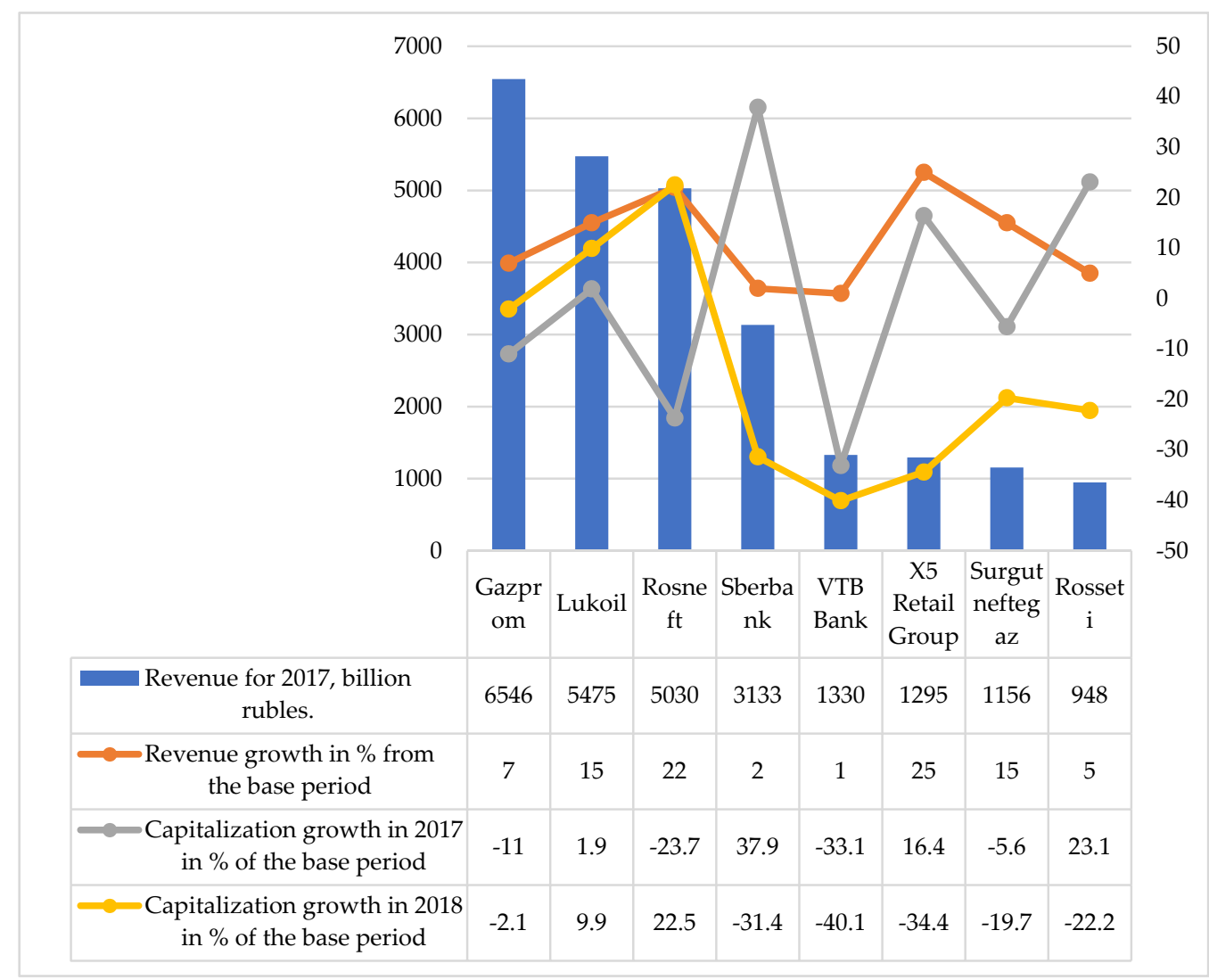

Figure 1. The most successful Russian issuers in 2017-2018. Compiled by the authors on the basis of Centralnyj Bank RF: Oficialnyj sajt (2021); Gavrilova (2019, 2021); Kommersant (2020).

Let us analyze the capitalization of the domestic stock market in Russia as of 31 December 2019, which amounted to 49 trillion RUB. In percentage terms, the increase was $22.5 \%$. Despite this, the number of issuers of shares traded on the Moscow Stock Exchange decreased by 212 companies or $4.1 \%$. The capitalization of 10 issuers amounted to $70.7 \%$, of which the largest five: Gazprom, Lukoil, Sberbank, Rosneft, and Novatek accounted for $50.6 \%$. The stock exchange growth of shares at the end of 2019 (excluding REPO) amounted to 12.4 trillion RUB, compared to 2018, the growth was 14.9\% (Moskovskaya birzha: Oficialnyj sajt 2019). The number of bond issuers traded on the Moscow Exchange increased to 354 companies, with an increase of $7.3 \%$ over the year. The government bond market grew by 9.3 trillion RUB or an increase of $18.5 \%$ in percentage terms. The market of sub-federal and municipal bonds is in a state of stagnation: 733 billion RUB (Cbonds 2019). The liquidity of the five most active instruments of foreign shares on the St. Petersburg Stock Exchange in percentage terms was as follows: as of 2016: 19.1\%, 2017: 87.1\%, 2018: 38.2\%, and 2019: 24.8\%. The liquidity of foreign shares of the St. Petersburg Stock Exchange 
in millions of USD as of 2016 was 533.7; in 2017 it was 3509.2; as of 2018 it was 5759.0; as of 2019 it was 16,708.4; the indicator of exchange turnover of foreign shares and ADRs (excluding repos) increased by $192.9 \%$ by the end of 2019 . Consequently, the number of issuers of shares increased to 1156 companies, where an increase since the beginning of the year amounted to $90.1 \%$, the share of the ten most liquid issuers on this stock exchange amounted to $40.5 \%$ of the turnover. The share of the five most liquid issuers in 2019 (Tesla, Amazon, AMD, Apple, Netflix) was $24.8 \%$.

The volume of the domestic corporate bonds market at par for the period of 2019 increased to 13.6 trillion rubles, an increase of 14.1\% (Cbonds 2019). Based on the material presented, it can be concluded that each country uses market models and strategies for its regulation in accordance with the concept of the market, its maturity, as well as the historical and cultural traditions of the country. Stock markets of countries that are successfully functioning and developing are a mechanism for economic development and the accumulation of funds. Comparing the stock markets of the United Kingdom and Brazil in this context, it should be noted that the United Kingdom is a striking example of the most developed stock market in Europe, while the stock market of Brazil is one of the most developed among developing countries. The United Kingdom is a developed country with an effective functioning of the financial sector of the economy, which uses a mono-regulatory model (Ademir Clemente and Espejo 2012; Batabyal and Robert 2021; Igor and Blokhina 2016; Kutuzova 2015; Nyasha and Odhiambo 2013). It consists in the fact that there is a single state authority that regulates the activities of all financial intermediaries without exception (Investing 2021). The following features are characteristic of the British stock market: a high level of mobilization of financial resources, investors' search for profitable industries, and their willingness to take risks, which contributes to the development of young and promising sectors of the economy as a whole: this model is quite promising. However, like many models, it has its drawbacks, including a focus on the short-term period and excessive requirements for the profitability of shares (Nyasha and Odhiambo 2013).

\subsection{Analysis of the Development's Dynamics of Stock Exchanges and Their Impact on the Financially Developed and Developing Markets}

The London Stock Exchange (LSE) is the largest stock exchange in Europe and one of the five largest stock exchanges in the world (Irina and Firsov 2021). About 775 million pounds are traded on it daily, and the average value of assets traded on the exchange is 5.3 billion pounds per day (Cbonds 2019). The market is dominated by issuers from the UK, where, during the analyzed period, the share of foreign companies on the exchange did not exceed $48 \%$ (Figure 2 ).

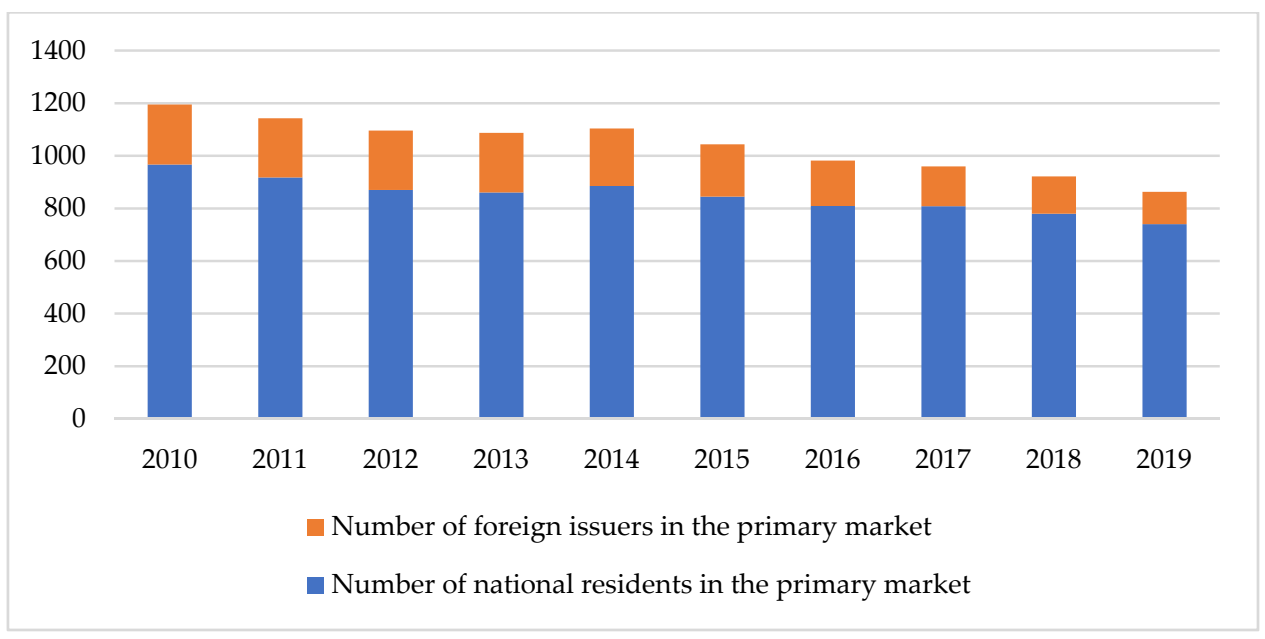

Figure 2. Dynamics of the number of issuers on the London Stock Exchange for 2010-2019. Compiled by the authors on the basis of London Stock Exchange (2021). 
This indicates that the main part of the resources are received by residents of the UK, which affects the development of the national economy.

Figure 3 shows that the increase in funds received on the exchange was the highest in 2012. This was due to an increase in the share of state issues of securities.

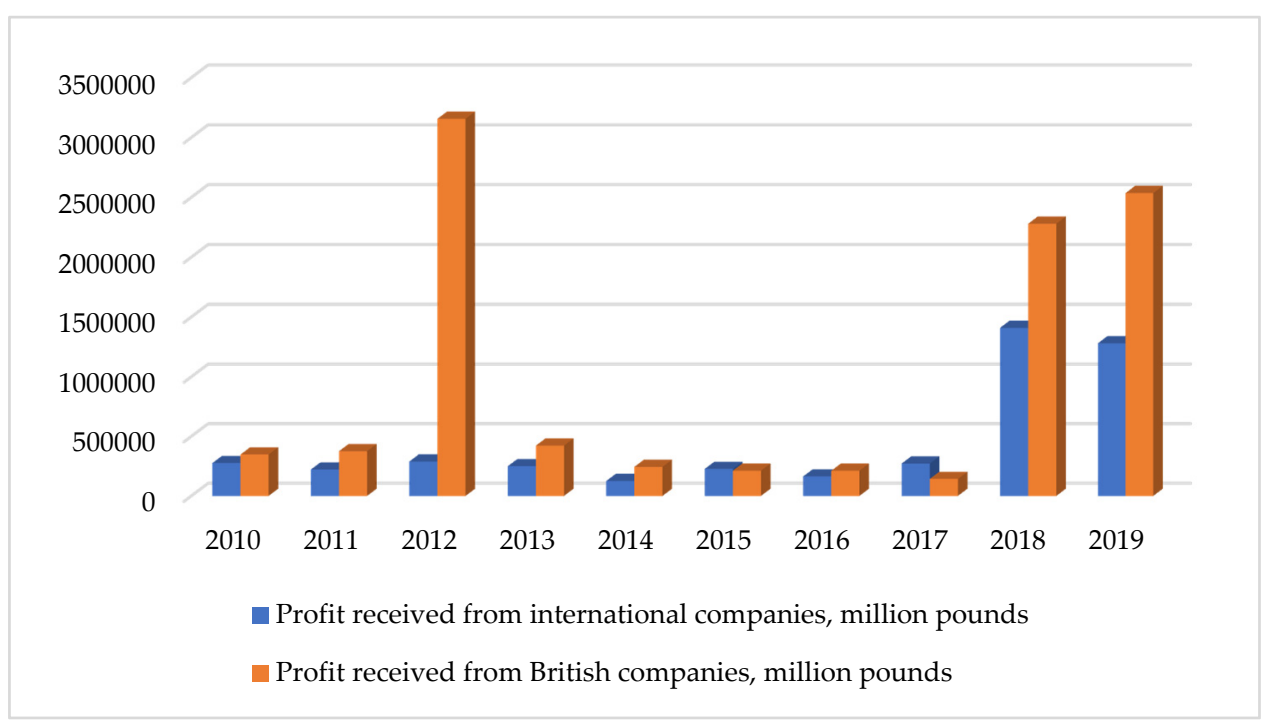

Figure 3. Dynamics of profit growth of the London Stock Exchange for 2010-2019. Compiled by the authors on the basis of London Stock Exchange (2021).

In general, the exchange demonstrates stability; therefore, it is a good foundation for the economy of developed countries. Unfortunately, the stock market of Brazil, which is at the stage of development, could not enjoy the advantages of stock exchanges for a long enough period. Long-term high inflation and general economic instability negatively impacted on the Brazilian stock market in the mid-1990s (Ademir Clemente and Espejo 2012). However, the market reacted positively to the changes and made significant progress. The number of available financial instruments has expanded, the market infrastructure has been reformed and strengthened, and a diversified investor base has been built.

Sao Paulo Stock Exchange (Bolsa de Valores de Sao Paulo/Bovespa (BM\&F Bovespa) was founded on 23 August 1890 and became the first exchange in Brazil. Now it is the largest stock exchange in Latin America (Nyasha and Odhiambo 2013). On 16 June 2017, the Brazilian Securities and Exchange Commission approved the change of the corporate name to B3 SA-Brasil, Bolsa, Balcão. Despite the measures taken and changes in the Brazilian stock exchanges, some problems are still present: the non-proliferation of long-term indexing, low liquidity in the secondary market, and a small number of listings. Comparing the London Stock Exchange and the main stock exchange of Brazil, it can be seen that the capitalization index for the first exchange is significantly higher than that of the second (Figure 4).

From the figure, we can draw these conclusions: on average, the amount of funds on the LSE exceeds B3 SA-Brasil, Bolsa, Balcão by almost 4 times; at the same time, B3 SA-Brasil, Bolsa, Balcão demonstrates an increase in the capitalization level by $13.25 \%$ in 2019 compared to 2018, while the same indicator for the LSE increased by $5.64 \%$ 


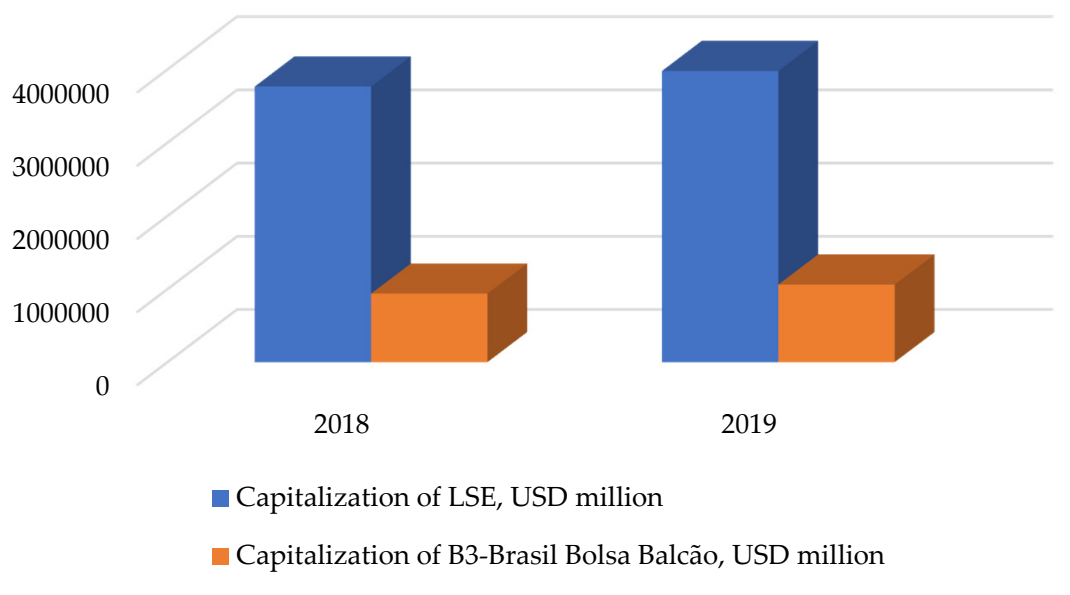

Figure 4. Comparison of the capitalization volumes of the main stock markets of the UK and Brazil for 2018-2019. Formed by the authors on the basis of The World Federation of Exchanges $(2018,2019)$.

Let us consider the number of companies listed on the stock exchanges (Figure 5).

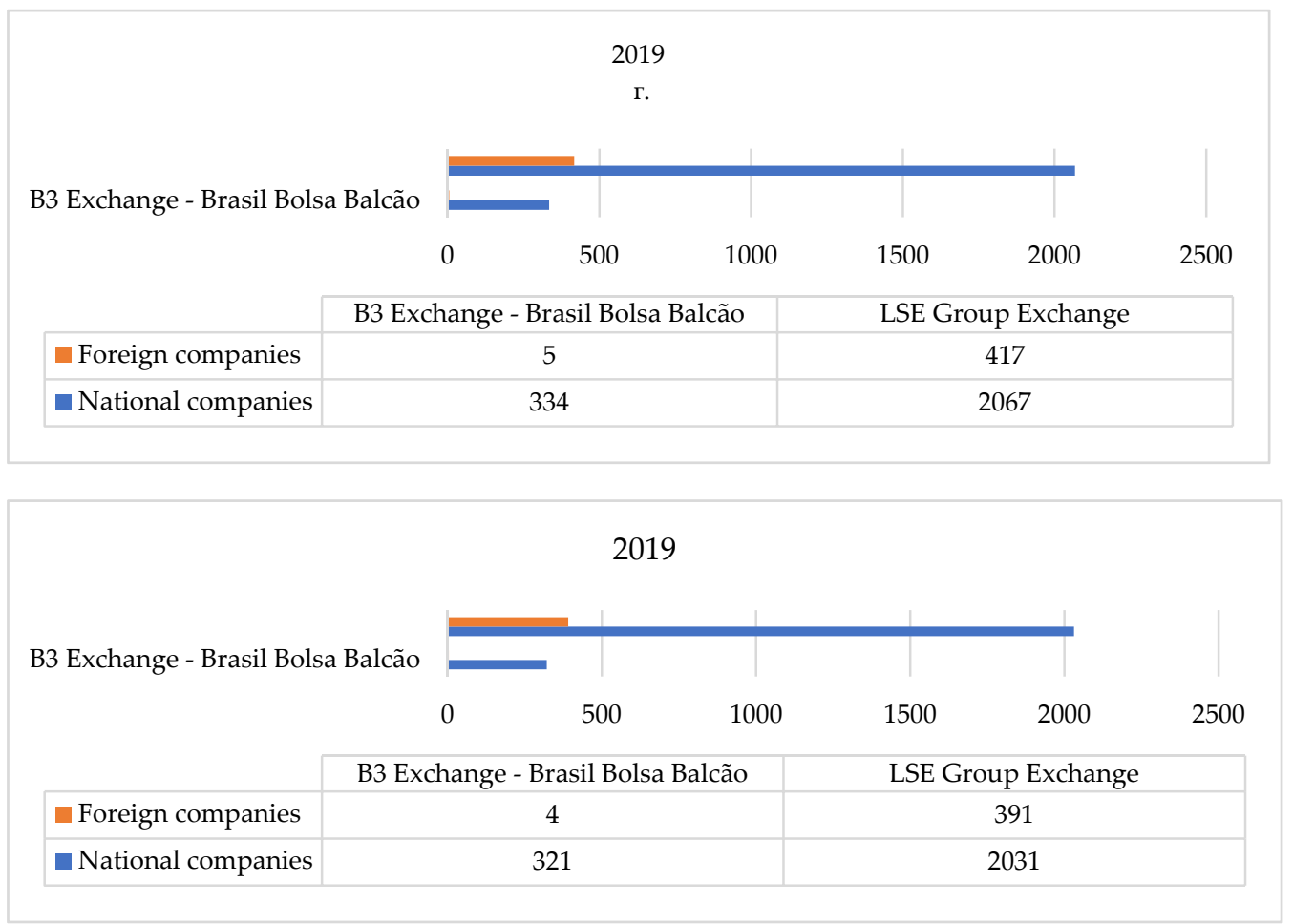

Figure 5. The number of companies listed on the B3 SA-Brasil exchanges, Bolsa, Balcão and LSE Group in 2018-2019. Formed by the authors on the basis of The World Federation of Exchanges (2019).

It is noticeable that the London Stock Exchange prevails in number, which indicates the scale of stock markets. The percentage of foreign companies is shown in Figure 6. 


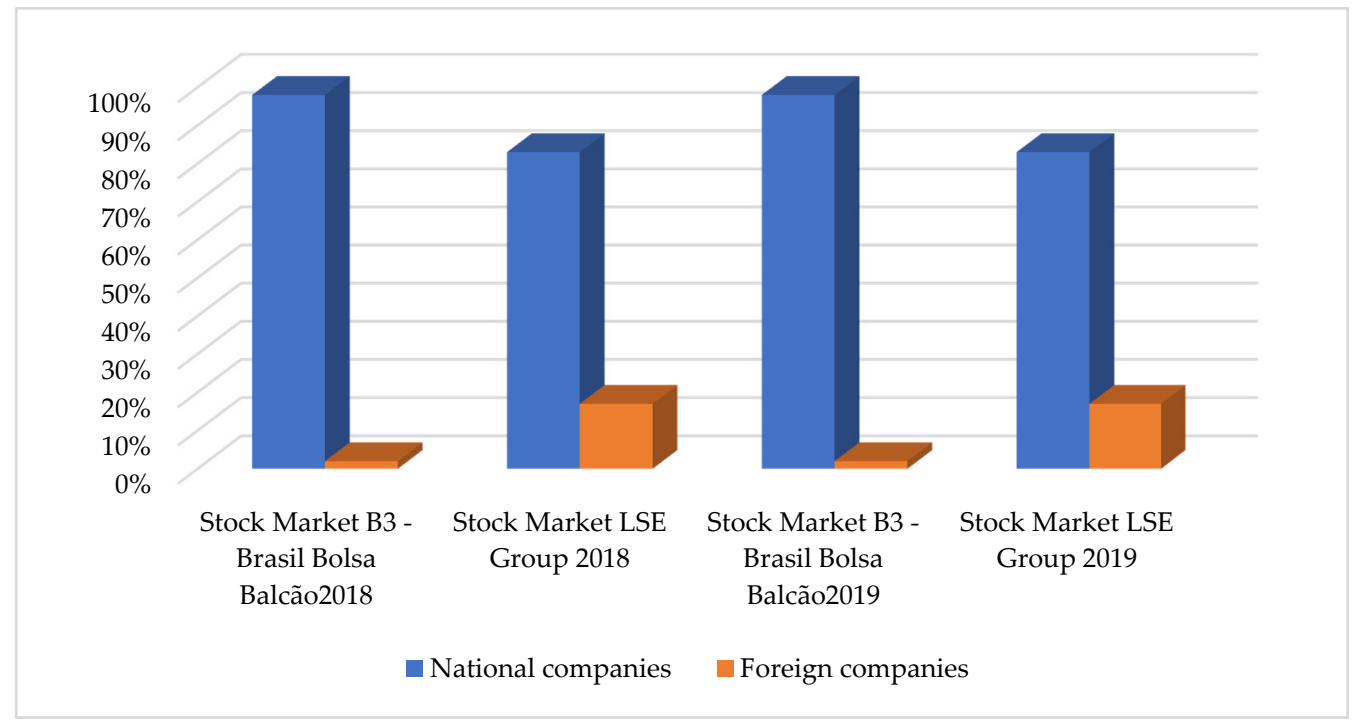

Figure 6. The percentage of national and foreign companies on the B3 SA-Brasil exchanges, Bolsa, Balcão and LSE Group in 2018-2019. Formed by the authors on the basis of The World Federation of Exchanges $(2018,2019)$.

The prevailing number of national companies indicate the contribution of stock exchanges' activities to the economy of the country where the exchange is registered. However, in percentage terms, the number of foreign firms prevails on the London Stock Exchange, meaning that the majority of non-resident issuers choose this stock market to place their securities.

The number and structure of companies admitted to the listing determine, respectively, the value of shares traded on the exchange. The total value of shares on both exchanges increased. At the same time, this amount increased by $9.9 \%$ on the LSE, and on the B3 SA-Brasil, Bolsa, Balcão by as much as $22.1 \%$. It is also worth paying attention to the fact that the foreign segment in the UK stock market is more developed than the similar segment in Brazil. The dynamics of its growth in the UK indicate its rapid development, and in Brazil it may indicate stagnation. It is known that on the exchanges of developing countries, risk premiums are higher than in developed markets, so the return on investment is greater (taking into account compensation when risk occurs). The total value of shares of national and foreign companies is shown in Table 1.

Table 1. The value of shares of national companies and foreign companies in 2018-2019.

\begin{tabular}{ccccccc}
\hline & \multicolumn{2}{c}{$\mathbf{2 0 1 8}$} & & & 2019 \\
\cline { 2 - 7 } Stock Market & $\begin{array}{c}\text { The Value of } \\
\text { Price }\end{array}$ & $\begin{array}{c}\text { The Value of } \\
\text { National } \\
\text { Companies }\end{array}$ & $\begin{array}{c}\text { Shares of } \\
\text { Foreign } \\
\text { Companies }\end{array}$ & $\begin{array}{c}\text { Total Share } \\
\text { Price }\end{array}$ & $\begin{array}{c}\text { The Value of } \\
\text { Shares of } \\
\text { National } \\
\text { Companies }\end{array}$ & $\begin{array}{c}\text { The Value of } \\
\text { Shares of } \\
\text { Foreign } \\
\text { Companies }\end{array}$ \\
\hline $\begin{array}{c}\text { B3 SA-Brasil, } \\
\text { Bolsa, Balcao }\end{array}$ & $666,670.2$ & $937,880.0$ & 2760.2 & $814,126.8$ & $969,195.23$ & 2876.7 \\
\hline LSE Group & $2,313,606.1$ & $3,766,535.8$ & $174,597.9$ & $2,541,532.0$ & $1,840,053.11$ & $198,182.0$ \\
\hline
\end{tabular}

Formed by the authors on the basis of The World Federation of Exchanges (2018).

The value of shares of foreign issuers traded on the London Stock Exchange increased by $13.5 \%$, and on B3 only by $4.22 \%$. Why is there such a striking difference between the indicators of the main stock exchanges of England and Brazil?

The answer is obvious: political uncertainty in the world order has played an important role in creating this situation. Since 1996, a number of political events have taken place in Brazil, the result of which was uncertainty, since there was a constant change in the 
conjuncture; an alternation of recession and favorable conditions for investment that greatly affected the situation. The country did not have a well-established management system, which affected the decrease in the inflow of foreign investment, which could be directed to promising industries. Historically, Brazilian investors are associated with a conservative form, where the rate in the country is determined as a percentage and is acceptable for "conservative" investors who invest in certificates of deposit. However, this situation began to change from the end of 2016; as a result, there was a decrease in the interest rate. Financial institutions and brokerage firms are working hard on the financial education of clients and portfolio reforms in order to adapt their clients' investment portfolio to the new stage of the Brazilian market (Irina and Firsov 2021).

The decade of hyperinflation and unstable national currency in the country is over. There is a long list of positive aspects that make Brazil a promising candidate for spectacular growth. Now Brazil has the highest potential among emerging markets due to a steadily growing economy, a stable financial market, and a liberal investment climate. However, to do this, it needs to continue its current course, avoiding shocks and sharp shifts (Igor and Blokhina 2016).

\section{Discussion}

The impact of the development of the stock market on the formation of investment attractiveness.

Non-resident investors, both individuals and legal entities, can invest in most of the financial and capital market instruments available to residents without any restrictions. However, they are required to conclude contracts with local organizations that perform storage functions and are representatives on management and tax issues. Investors also have to complete other formalities, such as registering with the Brazilian Central Bank, the stock market regulation, and Federal Revenue Service. Although the London Stock Exchange is significantly ahead in terms of share turnover, in the number of listed companies, and capitalization, Brazil shows positive trends. This indicates an improvement in the investment climate in the country. Brazil, like other emerging markets, is well positioned for new growth opportunities.

Like most emerging markets, investing in Brazil involves a compromise between a risk and a reward. Political instability and commodity dependence make it more risky than developed markets. A country rich in natural resources has prospects for the development of production not only of raw materials but also of goods. Obviously, there is a certain disparity in the level of growth between developed countries and developing countries, which can deepen the crisis phenomena in the budgetary and financial sectors of these countries. International investors can positively contribute to the growth and development of stock markets in developing countries. These markets offer a wide range of investment opportunities for investors. In the process of determining the factors that attract and deter investors, the World Federation of Exchanges conducted a survey of owners with large volumes of assets (Kandybko and Kandybko 2017; Zolotov 2013; Global Trade 2019).

The results of this survey showed that profit is important for investors, so their investment strategy will depend on how they assess the return on the investment object itself:

- $\quad$ investors exclude small markets or invest less in them than in large markets of developing countries;

- $\quad$ an important factor is the confidence in the ownership of shares;

- $\quad$ the length of time for opening investment accounts;

- $\quad$ liquidity concerns, needing a minimum liquidity threshold in order to invest;

- $\quad$ some investors believe that corporate governance (or lack of thereof) is a particular problem when investing in emerging markets, as is government intervention in business;

- $\quad$ market infrastructure is generally considered a necessary condition;

- $\quad$ all investors studied environmental, social, and managerial factors when evaluating their investments (The World Federation of Exchanges 2019). 
Investors have different approaches to assessing the attractiveness of investments in the country's emerging market, and this leads to different views on what is important for attracting them. However, in general, markets wishing to attract international investors should focus on the following:

- $\quad$ reducing the time and effort that investors spend on opening an investment account and investment expenses, such as taxes, especially if they relate to foreign investors;

- reduce the cost of information for investors and organize the provision of concise, accurate, and easily accessible information on how to open an investment account, relevant regulations, tax information, and local intermediaries;

- $\quad$ in many cases, investors invest in specific companies, although exchanges and regulators do not have control over the economic performance of companies, they can work to improve the quality of corporate reporting (both through the relevant listing requirements applied and by increasing the formation of companies);

- $\quad$ improving the market's structure (electronic trading system, after-sales service) will not attract investors to the market but will improve the understanding of the market, and, in some cases, if others are equal, can make the market more attractive; also, reporting according to international standards and disclosing it in English are factors that increase the attractiveness of companies in a certain market;

- $\quad$ the presence of strong local asset managers is a profitable and, sometimes, a determining circumstance of whether an investor will enter the market;

- $\quad$ the development of the local market is just as important as attracting international investors and can help attract these investors;

- $\quad$ although foreign investors are not too concerned about market fluctuations, a high level of volatility will reduce the attractiveness of the market for local firms that seek to raise capital, which will reduce the range of investment options (Syed and Sadorsky 2006; Butler et al. 2019; Evmenchik et al. 2021; Galanov and Galanova 2018; Nurpeisova et al. 2021; Patashkova et al. 2021; Patro et al. 2002). Brazil's experience in balancing the economy after the crisis helped it to pass the stage of the global financial crisis of 2008 relatively easily. However, the country needs investments and their effective use to accelerate the pace of development, which requires the effective functioning and scale of stock markets. Undoubtedly, the internal factors of the country's influence are also of great importance (Figure 7).

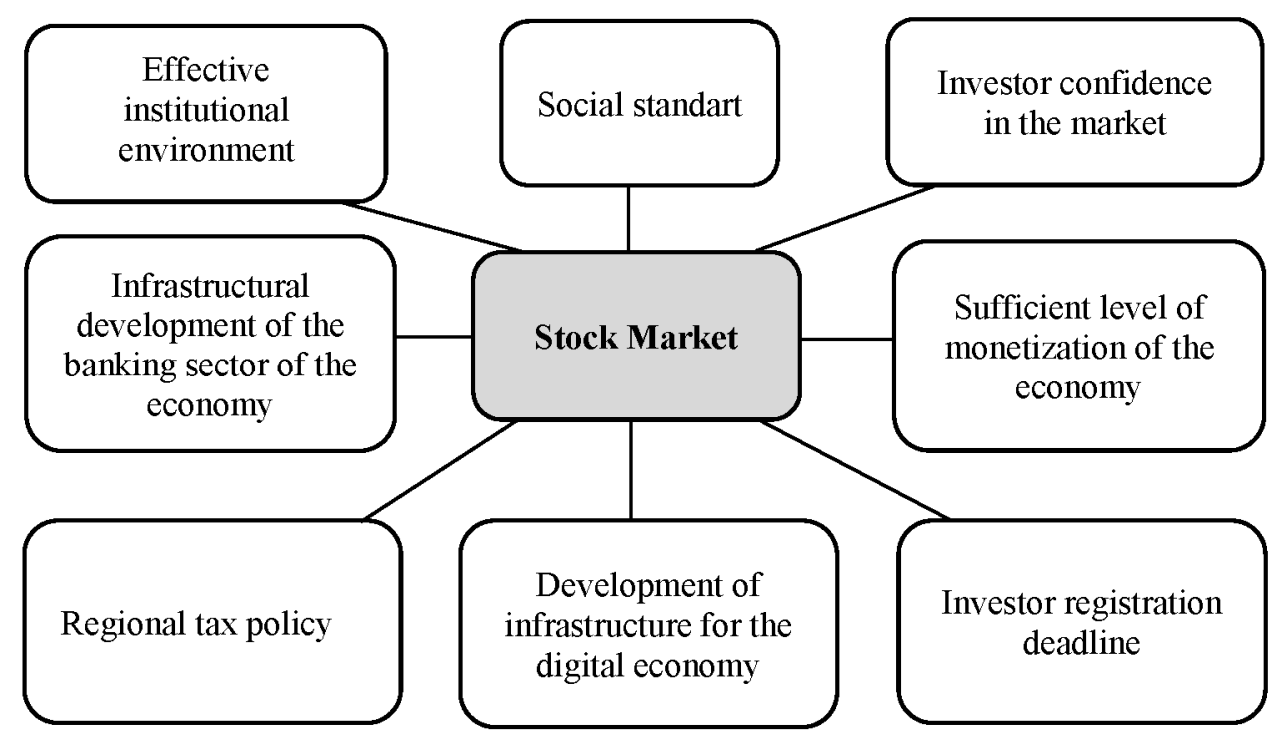

Figure 7. Internal factors influencing the Brazilian stock market. Formed by the authors on the basis of Ademir Clemente and Espejo (2012).

In Brazil, social norms form the national character. Accordingly, the formation of an investor's confidence in the stock market is influenced by morality, customs, and 
norms. Political and social stability determines the level of an investor's confidence in the exchanges, which also contributes to the attraction of long-term direct and portfolio investments to the market. For the effective functioning of the stock market in the country, there must be a favorable macroeconomic situation. Moreover, it was revealed during the research that the higher the level of monetization, the greater the capitalization of the stock market (Financial Conduct Authority 2020; Kurmankulova et al. 2021; Maisigova et al. 2021; Moldashbayeva et al. 2021; Patashkova et al. 2021). The tax burden should be a sufficient amount of financial resources and incentives for investment to remain at the disposal of the business.

As noted earlier, the UK uses a model in which non-bank financial and credit institutions have an active role. Indeed, when the Central Bank has too much of a share in the redistribution of monetary resources, it causes weakening of cash flows. Currency regulation and interest rates of central banks also have a significant impact on the development of financial mechanisms. As a rule, in developing countries, there are restrictions on foreign exchange transactions and restrictions for investors of the national securities market. This leads to low market liquidity and its dependence on external market factors of influence. If the country has high rates on government securities, this causes the transfer of monetary resources from the corporate sector, followed by a decline in the corporate segment (Ananev 2012; Sankt-Peterburgskaya birzha: Oficialnyj sajt 2019; UNCTAD 2019). The global stock market is now characterized by excessive volatility, which leads to instability of the economic system and causes the need to review the system of regulation of national financial markets. To ensure financial stability, it is necessary to implement a policy that includes a set of micro and macro tools. This is especially true for developing countries because their stock markets are weaker (Investing 2021; Zhang 2018; Zhurnal Financial One 2020). It is worth remembering that the research of the World Federation of Exchanges confirms that the main goal for investors is profit, but their investment activity is determined by the investment strategy. These differences lead to different views on what factors make the market more or less attractive from the point of view of investment, and it is important that investors differ even about the importance of matching with an emerging market and an already developed market.

For many, it was desirable to coordinate the market with the best international practices. For others, this correspondence, on the contrary, levels the desire to invest. Therefore, the improvement in the regulatory segment is important, especially at the current stage of economic development, but it is not an outstanding factor in attracting investment. This can be a good basis for the further development of exchanges and facilitations in their integration into the global economy.

\section{Conclusions}

In the course of the study, it was revealed that the macroeconomic environment is favorable for stock exchanges, which becomes the key to economic growth due to the influx of investments. Since the stock market is the center of accumulation of these investments for the analyzed countries, it is important for them to develop and properly transform this market through the introduction of digital technologies.

In this particular context, Brazil is still significantly behind the UK. The methods of regulating and organizing the market need to be improved, and the institutional environment is still vulnerable to sudden market fluctuations. According to the authors, to solve these problems, not only those of Brazil but also of all countries with emerging markets, the institutional environment needs to be improved, which will become a prerequisite for the stability of the stock market in such countries. The analysis of the world stock market is now characterized by excessive volatility; this process affects the stability of the economic system and causes an urgent need to improve the system of regulation of national stock markets. In order to ensure the stability of the financial system, a policy for the development of the financial and stock markets, including a set of tools and mechanisms, 
should be implemented at the macro and micro levels. Such methods will be especially relevant for developing countries since their stock markets are weaker.

Author Contributions: Conceptualization: S.N., M.A.K.J., L.B. and A.Z.; methodology: S.N., M.A.K.J., A.N., A.S. and L.B.; formal analysis: S.N., M.A.K.J., D.B, A.N., A.S. and A.Z.; investigation: S.N., A.S. and L.B.; resources: S.N., M.A.K.J., D.B., N.A., A.N. and A.S.; writing: original draft preparation, S.N., N.A. and A.Z.; writing: review and editing, S.N., L.B., A.N., N.A. and A.Z.; visualization: S.N., M.A.K.J., N.A., D.B., A.S., A.N. and A.Z.; supervision: S.N., M.A.K.J., N.A., L.B., A.S. and A.N. All authors have read and agreed to the published version of the manuscript.

Funding: This research received no external funding.

Institutional Review Board Statement: Not applicable.

Informed Consent Statement: Informed consent was obtained from all subjects involved in the study.

Data Availability Statement: The data used to support the findings of this study are available from the corresponding author upon request.

Conflicts of Interest: The author declares that he has no known competing financial interest or personal relationships with anyone that could have appeared to influence the work reported in this paper.

\section{References}

Ademir Clemente, Marinês Taffarel, and Robert A. Espejo. 2012. The Brazilian Stock Market-Dimension, Structure, and Main Features, Business Dynamics in the 21st Century, Chee-Heong Quah and Ong Lin Dar. Rijeka: IntechOpen. [CrossRef]

Ananev, Michail. 2012. Fundamental Factors in the Development of Stock Markets. Investicii: Praktika i opyt 17: 35-39. Available online: http://nbuv.gov.ua/UJRN/ipd_2012_17_10 (accessed on 12 December 2020).

Syed, Basher, and Perry Sadorsky. 2006. Oil price risk and emerging stock markets. Global Finance Journal 17: $224-51$.

Batabyal, Sourav, and Killins Robert. 2021. The Influence of Oil Prices on Equity Returns of Canadian Energy Firms. Journal of Risk and Financial Management 14: 226. [CrossRef]

Borsch, Ludmila. 2018a. The influence of fundamental factors and mechanisms on the development of the stock market. Scientific Bulletin: Finance, Banks, Investments 4: 153-64.

Borshch, Ludmila. 2018b. Influence of fundamental factors and mechanism on the development of the stock market. Nauchnyj vestnik: Finansy, Banki, Investicii 4: 153-64.

Andrey, Brodunov, and Vladimir Ushakov. 2015. Justification of Financial Decisions in Conditions of Uncertainty. Series 1: Economics and management; Moscow: Bulletin of the Witte Moscow University, vol. 1, pp. 30-36.

Butler, Alexander, Larry Fauver, and Ioannis Spyridopoulos. 2019. Local Economic Spillover Effects of Stock Market Listings. Journal of Financial and Quantitative Analysis 54: 1025-50. [CrossRef]

Cbonds. 2019. Bond Market Statistics. Available online: https:/ / cbonds.ru/indexes / ?viewTree=1\&group=2\%E2\%80\%933k.5\%E2\%80\% 93b8jk.6\%E2\%80\%931nxfk.7\%E2\%80\%933ovc\&\%D1\%8E (accessed on 20 February 2021).

Centralnyj Bank RF: Oficialnyj sajt. 2021. Available online: http:/ / www.cbr.ru/ (accessed on 20 March 2021).

Evmenchik, Oksana, Favziya Seidakhmetova, and Tatyana Mezentceva. 2021. The Role of Gross Profit and Margin Contribution in Decision Making. In Socio-Economic Systems: Paradigms for the Future. Edited by E. Popkova, Ostrovskaya and A. Bogoviz. Studies in Systems, Decision and Control. Cham: Springer, vol. 314. [CrossRef]

Ferreira, Talieh, Gustavo Xavier, and Orleans Martins. 2018. Political Uncertainty and Risk Premium in the Brazilian Stock Market. Journal of Financial Innovation. Available online: https:/ / ssrn.com/abstract=3161831 (accessed on 20 March 2021).

Filatova, Svetlana. 2017. The main directions of development and features in ensuring the stability of the functioning of the national payment system of Russia. Problemy Ekonomicheskoj Nauki i Praktiki 2: 95-101.

Financial Conduct Authority. 2020. Primary Markets, Regulatory Disclosures. Available online: https://marketsecurities.fca.org.uk/ regulatory-disclosures (accessed on 20 March 2021).

Irina, Firsova, and Yuri Firsov. 2021. Development of financial markets. Financial Life 2: 61-65.

Galanov, Vladimir, and Aleksandra Galanova. 2018. The Law on the Securities Market as the Law on Financial Markets. Plekhanov. Finance Money Circulation and Credit. Moskow: Bulletin of the Russian University of Economics, vol. 1, pp. 68-75.

Gavrilova, Eleanora. 2019. Investment Banking as a Direction of Banking Activity: Essence, Features and Problems of Development. Series 1: Economics and Management; Moskow: Bulletin of the Witte Moscow University, vol. 4, pp. 81-86. [CrossRef]

Gavrilova, Eleanora. 2021. Modern Investment in the Market of Brokerage Services. Series 1: Economics and Management; Bulletin of the S.Y. Moskow: Witte Moscow University, vol. 3, pp. 39-45. [CrossRef]

Global Trade. 2019. New challenges for Brazilian Markets. Available online: https:/ /www.globaltrademag.com/new--challenges--for-brazilian--markets / (accessed on 20 March 2021). 
Igor, Grekov, and Tatyana Blokhina. 2016. The influence of macroeconomic factors to the dynamics of stock exchange in the Republic of Kazakhstan. Economy of Region 12: 1263-73. [CrossRef]

Investing. 2021. World Financial Markets. Available online: https://ru.investing.com/markets/ (accessed on 20 March 2021).

Investopedia. 2020. London Stock Exchange (LSE). Available online: https://www.investopedia.com/terms/1/lse.asp (accessed on 20 March 2021).

Ivanova, Olga, Buldyryk Suleimenova, Saltanat Yerzhanova, and Rysty Berstembayeva. 2021. Oil and Gas Investment Opportunities for Companies in Modern Conditions. In Socio-Economic Systems: Paradigms for the Future. Studies in Systems, Decision and Control. Edited by E. Popkova, V. Ostrovskaya and A. Bogoviz. Cham: Springer, vol. 314. [CrossRef]

Kandybko, Nataliya, and Oleg Kandybko. 2017. Conceptual Model of the Securities Market Forecast Using Fundamental Analysis Methods. Series 1: Economics and Management; Bulletin of the S.Y. Moskow: Witte Moscow University, vol. 3, pp. 44-49. [CrossRef]

Kommersant. 2020. Bonds Will Be Removed from Qualification. Available online: https://www.kommersant.ru/doc/3739863 (accessed on 21 March 2021).

Kulikova, Vera. 2018. Development of the Russian stock market under the influence of changes in financial regulation. Finansovaya zhizn 1: 95-99.

Kurmankulova, Roza, Svetlana Anzorova, Makka Goigova, and Zeinegul Yessymkhanova. 2021. Digital Transformation of Government Procurement on the Level of State Governance. In Socio-Economic Systems: Paradigms for the Future. Studies in Systems, Decision and Control. Edited by E. Popkova, Ostrovskaya and A. Bogoviz. Cham: Springer, vol. 314. [CrossRef]

Kutuzova, Marina. 2015. Formation and development of the stock market: Theoretical aspects. Nauka 21 Veka: Voprosy, Gipotezy, Otvety 3: 100-3.

Thai-Ha, Le, and Youngho Chang. 2011. The Impact of Oil Price Fluctuations on Stock Markets in Developed and Emerging Economies. Singapore: Economic Growth Centre Division of Economics School of Humanities and Social Sciences Nanyang Technological University 14 Nanyang Drive.

London Stock Exchange. 2021. Main Market Factsheet (2010-2019). Available online: https://www.londonstockexchange.com/ reports?tab=main--market (accessed on 21 March 2021).

Maisigova, Leila, Bibigul Isayeva, and Tamara Dzholdosheva. 2021. Features of Relations between Government Authorities, Business, and Civil Society in the Digital Economy. In Socio-Economic Systems: Paradigms for the Future. Studies in Systems, Decision and Control. Edited by E. Popkova, V. Ostrovskaya and A. Bogoviz. Cham: Springer, vol. 314. [CrossRef]

Moldashbayeva, Luiza, Bakhytzhamal Zhumatayeva, Tatiana Mezentseva, and Larisa Shirshova. 2021. Digital Economy Development as an Important Factor for the Country's Economic Growth. In Socio-Economic Systems: Paradigms for the Future. Studies in Systems, Decision and Control. Edited by E. Popkova, V. Ostrovskaya and A. Bogoviz. Cham: Springer, vol. 314. [CrossRef]

Moskovskaya birzha: Oficialnyj sajt. 2019. Moscow Exchange Announces Financial Results for 2019. Available online: https: / / www.moex.com/n27206?utm_source=www.moex.com\&utm_term=\%D0\%BA \%D0\%B0\%D0\%BF\%D0\%B8\%D1\%82\% D0\%B0\%D0\%BB $\%$ D0\%B8\%D0\%B7\%D0\%B0\%D1\%86\%D0\%B8\%D1\%8F (accessed on 25 March 2021).

Nurpeisova, Ardak, Laila Smailova, Bibigul Akimova, and Elena Borisova. 2021. Condition and Prospects of Innovative Development of the Economy in Kazakhstan. In Socio-Economic Systems: Paradigms for the Future. Studies in Systems, Decision and Control. Edited by E. Popkova, V. Ostrovskaya and A. Bogoviz. Cham: Springer, vol. 314. [CrossRef]

Nyasha, Sheilla, and NM Odhiambo. 2013. The Brazilian stock market development: A critical analysis of progress and prospects during the past 50 years. Risk Governance and Control: Financial Markets E Institutions 3: 7-15. [CrossRef]

Parker Simon. 2018. Venture Capital and Business Angel Finance. In The Economics of Entrepreneurship. Cambridge: Cambridge University Press, pp. 365-390. [CrossRef]

Patashkova, Yelena, Seyit Kerimkhulle, Madina Serikova, and Marija Troyanskaya. 2021. Dynamics of Bitcoin trading on the Binance cryptocurrency exchange. Economic Annals-XXI. [CrossRef]

Patro, Dilip, John Wald, and Yangru Wu. 2002. Explaining exchange rate risk in world stock markets: A panel approach. Journal of banking and Finance 26: 1951-72. [CrossRef]

Saifiev, Sergey, and Sergey Soloviev. 2019. The possibilities of expanding Russian financial operations in global markets and the development of an international financial center in Russia. Finance and Credit 4: 5-14.

Sankt-Peterburgskaya birzha: Oficialnyj sajt. 2019. Market Data. Available online: https://spbexchange.ru/ru/market--data/default. aspx\#3 (accessed on 25 March 2021).

Taylan, Ali Sarbri, and Huseyin Tatlidil. 2013. After 2008 Global Financial Crisis, Short-Term Dynamics of CDS, Bond, and Stock Markets in South Eastern European Economies: Evidence from Panel VAR Methodology. In Technology and Financial Crisis: Economical and Analytical Views. Hershey: IGI Global, pp. 181-94.

The World Federation of Exchanges. 2018. WFE Annual Statistics Guide (Volume 4). Available online: https: / www.world--exchanges. org/our--work/articles/wfe--annual--statistics--guide--volume--4 (accessed on 25 March 2021).

The World Federation of Exchanges. 2019. Investing in Emerging and Frontier Markets-An Investor Viewpoint. Available online: https:/ / www.world--exchanges.org/storage/app/media/research (accessed on 25 March 2021).

UNCTAD. 2019. The World Investment Report 2019. Available online: https:/ / unctad.org/webflyer/world--investment--report--2019 (accessed on 25 March 2021).

Zaharova, Anna, and Marina Vilisova. 2016. The main trends in the development of the securities market in the modern economic conditions. Nauka i Innovacii v Sovremennyh Usloviyah 15: 151-54. 
Zhang, Zhong. 2018. Law and Economic Growth in China: A Case-Study of the Stock Market. Asian Journal of Law and Society 5: 333-57. [CrossRef]

Zhurnal Financial One. 2020. Available online: https:/ / fomag.ru/ (accessed on 25 May 2021).

Zolotov, Aleksey. 2013. The Development of Financial Markets in the Context of Globalization. Series 1: Economics and Management; Bulletin of the S.Y. Moscow: Witte Moscow University, vol. 2, pp. 81-87. 